\title{
N Sources Affect Growth, Nutrient Content, and Net Photosynthesis in Maté (Ilex paraguariensis St. Hil.)
}

\author{
Sérgio Gaiad $^{1 *}$, Miroslava Rakocevic ${ }^{1}$ and Carlos Bruno Reissmann ${ }^{2}$ \\ ${ }^{1}$ Embrapa Floresta; C. P. 319; 83411-000; Colombo - PR - Brasil. ${ }^{2}$ Universidade Federal do Paraná; \\ Departamento de Ciências do Solo; Rua dos Funcionários 1540; 80035-050; Curitiba - PR - Brasil
}

\begin{abstract}
The influence of different $N$ sources on the growth of maté (Ilex paragurariensis St.Hil.) seedlings grown in greenhouse was studied. All seedlings received a base fertilization of $10 \mathrm{mg} \mathrm{N} \cdot \mathrm{kg}^{-1}$ soil as $\mathrm{NH}_{4} \mathrm{NO}_{3}, 60 \mathrm{mg} \mathrm{P}_{2} \mathrm{O}_{5}$. and

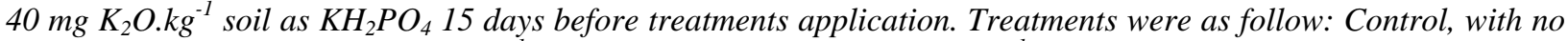

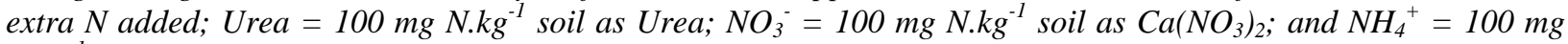

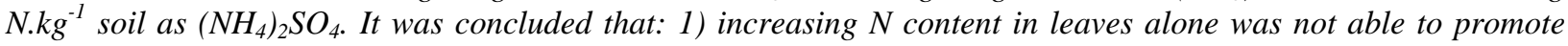
gain in biomass production of maté seedlings; 2) seedlings receiving $\mathrm{N}-\mathrm{NH}_{4}$ showed a higher accumulation of $\mathrm{P}$ and $\mathrm{Mg}$ on shoot biomass; and 3) an increase in leaf area, leaf number and net photosynthesis observed at the $\mathrm{N}_{-} \mathrm{NH}_{4}$ treatment was coincident with an increasing absorption of $P$ and $M g$.
\end{abstract}

Key words: Ammonium, nitrate, soil $\mathrm{pH}$

\section{INTRODUCTION}

Maté (Ilex paraguariensis, St. Hil.) is a native tree from South Brazil, Paraguay and Argentina (Hoppe et al., 1996). It is grown mainly by small farmers which gives it a great social-economical importance. It naturally occurs on soils with low levels of nutrients and high level of $\mathrm{Al}^{3+}$, generally with a medium to clay texture (Oliveira and Rotta, 1985) and do not grow well in shallow soils (Dedecek, 1997). Nitrogen is consumed in high amounts during maté harvesting (Reissmann et al., 1985; Wisniewski et al., 1996), reaching up to the equivalent to $500 \mathrm{~kg}$ Urea.ha $^{-1}$.year ${ }^{-1}$ (Lourenço, 1997). Therefore the replacement of $\mathrm{N}$ seems to be essential for maté sustainability.

Usually plants are able to take up $\mathrm{N}$ as nitrate $\left(\mathrm{NO}_{3}{ }^{-}\right)$and ammonium $\left(\mathrm{NH}_{4}{ }^{+}\right)$, but some may prefer one source or another depending on plant species (Marschner, 1995). N sources may affect plant growth via many processes within the soilplant system, and inside the plant (Wiesler, 1997). The use of different $\mathrm{N}$ sources may directly affect the nutrition status of plants due to changes in the rhizosphere, as a result of modification in the ionic balance in that soil fraction. The use of $\mathrm{N}^{-\mathrm{NH}_{4}}$ causes an increasing $\mathrm{H}^{+}$excretion, leading to a decrease in soil $\mathrm{pH}$, whereas the use of $\mathrm{N}-\mathrm{NO}_{3}$ is associated with a decrease in $\mathrm{H}^{+}$excretion and increasing rates of $\mathrm{HCO}_{3}{ }^{-}$or $\mathrm{OH}^{-}$resulting in a $\mathrm{pH}$ rise, especially when in combination with $\mathrm{Ca}^{2+}$ (Marschner and Römheld, 1996). However, when plants growing in a similar way are supplied with $\mathrm{N}-\mathrm{NO}_{3}$ or $\mathrm{N}-\mathrm{NH}_{4}$, they may differ in many aspects related to metabolic activity and ionic composition (Kandlbinder et al., 1997), as a result of different physiological responses.

\footnotetext{
${ }^{*}$ Author for correspondence
} 
The reduction of $\mathrm{N}-\mathrm{NO}_{3}$ in plants consume great amount of reducing power. Considering the biochemical energy needed for $\mathrm{NO}_{3}$ reduction, one could suppose that plant supplied with $\mathrm{N}_{-} \mathrm{NH}_{4}$ would grow better than that supplied with $\mathrm{N}-\mathrm{NO}_{3}$ source, however in most cases the opposite occurs even altering the plant architecture of fast growing plants (Beltrano et al., 1999).

Some species show growth depression when supplied exclusively with $\mathrm{N}-\mathrm{NH}_{4}$, but generally this causes a decrease in soil $\mathrm{pH}$ which may increase the availability of some mineral nutrients such as $\mathrm{P}, \mathrm{Fe}, \mathrm{Mn}, \mathrm{Cu}$, and $\mathrm{Zn}$ (Marschner, 1995), improving the soil/plant relationship depending on soil conditions. $\mathrm{N}$ transfer from roots to leaves can occur in different manners (Pate, 1973) and its incorporation in different amino acids, proteins, and other $\mathrm{N}$ compounds are differentiated for each plant species and development stage. The limit for $\mathrm{N}-\mathrm{NO}_{3}$ and $\mathrm{N}-\mathrm{NH}_{4}$ absorption and assimilation can be carbon metabolism in the first place (depending on radiation and photosynthesis) for the carbon skeleton formation of amino acids, as well as $\mathrm{N}$ metabolites by itself working on the assimilation repression (Imsande and Touraine, 1994). On the other hand, using the Farquhar et al. (1980) equations, considering temperature and $\mathrm{CO}_{2}$ concentration constant, the photosynthesis can be limited by radiation and $\mathrm{N}$ content (Paul and Foyer, 2001).

In the construction of a dynamic allocation model in the plant, Soussana et al. (2000) used the hypothesis of a co-limitation of growth by light and mineral $\mathrm{N}$. They considered that these two resources, independently, would be used in the construction of structural compartments (shoot structural components, roots components, and leaf proteins), and among them it would be established a relationship of coordination of $\mathrm{N}$ absorption and photosynthesis. The aim of this research was to evaluate biomass production, nutrient content, net photosynthesis and morphogenesis in maté seedlings in response to different $\mathrm{N}$ sources.

\section{MATERIAL AND METHODS}

\section{Seedling preparation and treatments}

Maté seedlings (four months old) were selected according to their phenotypic characteristics (size, number of leaves, and general aspect). The root system was reduced to about $50 \%$ and the seedlings were bare root transplanted to $1.3 \mathrm{~kg}$ plastic bags. The soil used as substrate was an Oxisol with: $\mathrm{pH}\left(\mathrm{CaCl}_{2}\right)=4,00 ; \mathrm{K}^{+}=0,09 \mathrm{cmol}_{\mathrm{c}} \cdot \mathrm{dm}^{-}$ 3. $\mathrm{Ca}^{2+}=0,97 \mathrm{cmol}_{\mathrm{c}} \cdot \mathrm{dm}^{-3} ; \mathrm{Ca}+\mathrm{Mg}=2,31 \mathrm{cmol}_{\mathrm{c}} \cdot \mathrm{dm}^{-3}$; $\mathrm{Al}^{3+}=2,38 \quad \mathrm{cmol}_{\mathrm{c}} \cdot \mathrm{dm}^{-3} ; \mathrm{H}+\mathrm{Al}=8,50 \quad \mathrm{cmol}_{\mathrm{c}} \cdot \mathrm{dm}^{-3}$; $\mathrm{MO}=24,99 \mathrm{~g} \cdot \mathrm{kg}^{-1} ; \mathrm{P}=1,00 \mathrm{mg} \cdot \mathrm{kg}^{-1}$; and $\mathrm{Na}^{+}=7,00$ $\mathrm{mg} \cdot \mathrm{kg}^{-1}$. The experiment was conducted from September to December 2002, in greenhouse condition at the National Centre for Forestry Research (Embrapa Forestry).

Seedlings were allowed to grow with no treatment at all for 35 days from transplanting until completely established during September/October, 2002. An equilibrium nutrient solution containing $10 \mathrm{mg} \mathrm{N} \cdot \mathrm{kg}^{-1}$ soil as ammonium nitrate $\left(\mathrm{NH}_{4} \mathrm{NO}_{3}\right)$, $60 \mathrm{mg} \mathrm{P} \mathrm{P}_{2} \cdot \mathrm{kg}_{-}{ }^{1}$ soil and $40 \mathrm{mg} \mathrm{K} \mathrm{O}_{2} \mathrm{O}^{-1}{ }^{-1}$ soil as potassium phosphate $\left(\mathrm{KH}_{2} \mathrm{PO}_{4}\right)$ was applied in all seedlings aiming to balance the nutrient availability for all treatments. Seedlings were then allowed to grow for 15 days. After that period, four treatments were set up: Control = no extra $\mathrm{N}$ applied; Urea $=100 \mathrm{mg} \mathrm{N} . \mathrm{kg}^{-1}$ soil supplied with Urea source; $\mathrm{N}-\mathrm{NO}_{3}=100 \mathrm{mg} \mathrm{N} \cdot \mathrm{kg}^{-1}$ soil supplied with $\mathrm{Ca}\left(\mathrm{NO}_{3}\right)_{2}$; and $\mathrm{N}-\mathrm{NH}_{4}=100 \mathrm{mg} \mathrm{N} \cdot \mathrm{kg}^{-1}$ soil supplied with $\left(\mathrm{NH}_{4}\right)_{2} \mathrm{SO}_{4}$. Seedlings were watered daily.

\section{Net photosynthesis and morphological aspects}

Eight seedlings per treatment were selected for net photosynthesis measurements and morphological characteristics determination. Selected seedlings presented 8-9 leaves and similar height, size of leaves, and general aspect. The following morphological characteristics were evaluated: seedling height $(\mathrm{cm})$, internodes length $(\mathrm{cm})$ leaves number, length and width and-physiological state of each leaf (mature or new). Those parameters were evaluated three times: a) one day before the treatments were applied (start); b) 10 days after treatments were applied; c) 25 days after treatments were applied. Leaf length and width were used to calculate the leaf area (LA) per plant $\left(\mathrm{cm}^{2}\right.$. plant $\left.^{-1}\right)$.

The net photosynthesis $(\mathrm{Pn})$ or rate of carbon dioxide exchange $\left(\mu \mathrm{mol} \quad \mathrm{CO}_{2} \cdot \mathrm{m}^{-2} \cdot \mathrm{s}^{-1}\right)$ was measured using a portable analysis system (model LI-6200, LICOR, Inc. Lincoln, NE, USA). The first evaluation of photosynthesis and morphology was made before fertilization application. The leaves were marked in order to use the same ones in all evaluations. In the first evaluation, only the fully expanded leaves were marked (considered as "mature"), and after 10 days, additionally, new emitted leaves still in expansion ("young") were 
also marked. The measurements of Pn were taken outside the greenhouse. The radiation microclimatic conditions were evaluated on a basis of sequential measurements obtained by LI-190AS radiation sensor, (measure photosynthetically active radiation - PPFD on the 400-700nm waveband in $\mu$ mol. $\left.\mathrm{m}^{-2} \cdot \mathrm{s}^{-1}\right)$, LI-200AS Pyranometer sensor, (measures solar irradiation in $\mathrm{W} \cdot \mathrm{m}^{-2} \cdot \mathrm{s}^{-1}$ ), and by SKY $110(660 / 730)$ sensor measures red: far-red ratio. Sensors were positioned on maté seedlings level during 9 days in greenhouse. Values were registered as means calculated for periods of 15 minutes.

\section{Biomass and chemical composition}

The first evaluation of biomass parameters was made at the same time as the 10 days observation for photosynthesis and morphological parameters. For this purpose, six plants were harvested per block and seedlings were divided in leaves, stem and roots. This material was oven dried $\left(60^{\circ} \mathrm{C}\right)$ until constant weight and data were recorded. The shoot analysis was performed using Micro Kjeldal Sulfuric Acid Digestion for Nitrogen and NitroPerchloric Acid Digestion for $\mathrm{P}, \mathrm{K}, \mathrm{Ca}, \mathrm{Mg}, \mathrm{Cu}$, $\mathrm{Fe}, \mathrm{Mn}$ and $\mathrm{Zn}$. The determination of the elements was made using distillation and titillation for $\mathrm{N}$, colorimetry for $\mathrm{P}$, flame photometry for $\mathrm{K}$ and atomic absorption spectrometry - flame for $\mathrm{Ca}$, $\mathrm{Mg}, \mathrm{Cu}, \mathrm{Fe}, \mathrm{Mn}$ and $\mathrm{Zn}$.

\section{Experimental design and Statistical analysis}

Treatments were distributed in randomized blocks in three replicates and twelve seedlings per plot in a total of 36 seedlings per treatment.Data were statistically analyzed using the Tukey test on a confidence interval of $10 \%$ of probability.

\section{RESULTS}

Average diurnal value of irradiation in plant level, for the experimentation period in glasshouse was 7.7 MJ.day ${ }^{-1}$. The PPFD reaching leaves of maté reduced on maximum value of de $800 \mu \mathrm{mol} . \mathrm{m}^{-2} . \mathrm{s}^{-1}$, in midday period (Fig. 1A) compared with values which arrive on superior canopy level in nature (to $\left.2200 \mu \mathrm{mol} . \mathrm{m}^{-2} \cdot \mathrm{s}^{-1}\right)$, on the same period of the day, year, and on the same region. The red: far-red ratio (R:FR) was not affected in the greenhouse as compared to open areas (Fig. 1B).

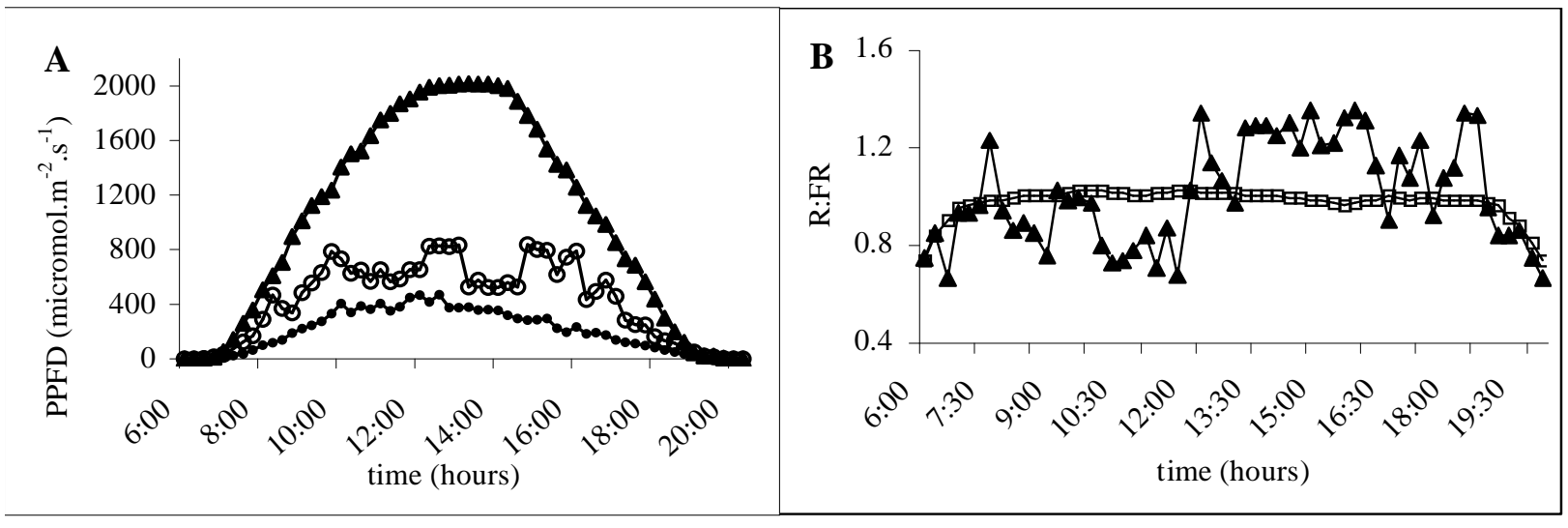

Figure 1 - (A) PPFD on plant level registered during 9-day-period (average curve), comparing the sunny ( $\mathbf{A})$ and cloudy $(\mathrm{O})$ days outside the glasshouse and average inside of glasshouse $(\bullet)$. (B) Average red: far-red ratio (R: FR) on plant level outside $(\boldsymbol{A})$ and inside $(\square)$ of glasshouse.

Maté seedlings showed different responses to distinct $\mathrm{N}$ sources (Figs. 2 to 6). Seedlings that received $\mathrm{N}-\mathrm{NH}_{4}$ and $\mathrm{N}-\mathrm{NO}_{3}$ presented a higher number of leaves after 25 days as compared to Control and Urea treatments (Fig. 2). The number of leaves was directly related to lateral branching. In the last harvest, 25 days after treatment were applied, from the eight seedlings selected to net photosynthesis evaluation five presented lateral branching in $\mathrm{N}-\mathrm{NH}_{4}$, one in $\mathrm{N}-\mathrm{NO}_{3}$ and none in urea and control treatments.

The increase in leaf area $\left(\mathrm{LA}, \mathrm{cm}^{2} \cdot\right.$ plant $\left.^{-1}\right)$ also differed depending on the $\mathrm{N}$ source used (Fig. 3). Seedlings exhibited a phenotypic homogeneity prior to $\mathrm{N}$ treatments application not showing difference among treatments at the start point of 
the experiment. In the first evaluation, 10 days after treatments application, LA of plants fertilized with urea was higher than seedlings that received the sources $\mathrm{N}-\mathrm{NH}_{4}$ and $\mathrm{N}-\mathrm{NO}_{3}$ but did not differ from the control. A significant increase in LA was detected in all treatments, especially in the $\mathrm{N}^{-\mathrm{NH}_{4}}$ and in the $\mathrm{N}-\mathrm{NO}_{3}$, between the $10^{\text {th }}$ and $25^{\text {th }}$ day. At that time, there was no difference among treatments, however, the inclination of the lines representing the treatments, showed steeper angles in the treatments $\mathrm{N}-\mathrm{NO}_{3}$ and $\mathrm{N}-\mathrm{NH}_{4}$ indicating a tendency of higher increase in LA in those treatments than in urea or control (Fig. 3).

The emission of ramifications, total number of leaves and LA affected the increase in shoot biomass (Fig. 4A) and the increment of both total and shoot biomass of seedlings (Fig. 4B) from the $10^{\text {th }}$ to the $25^{\text {th }}$ day after treatments application.
Distinct responses according to $\mathrm{N}$ source were noticed in differences on absorption capacity of nutrients by maté seedlings (Table 1). There was also an accumulation of $\mathrm{N}$ in the treatments that received any $\mathrm{N}$ source in relation to control. The $\mathrm{N}-\mathrm{NH}_{4}$ source showed a higher absorption of $\mathrm{P}$ and $\mathrm{Mg}$ as compared to control and $\mathrm{N}-\mathrm{NO}_{3}$ treatments (Table 1).

The use of different $\mathrm{N}$ sources was responsible for a higher biomass production per plant (Fig. 4) and higher $\mathrm{N}$ content in shoots (Fig. 5) as compared to control treatments It was observed yet a higher biomass increase between $10^{\text {th }}$ and $25^{\text {th }}$ day of $\mathrm{N}$ application (Fig. 4B) on urea and $\mathrm{N}_{-} \mathrm{NH}_{4}$ treatments in relation to the $\mathrm{N}-\mathrm{NO}_{3}$ source, but no difference between $\mathrm{N}$-sources in shoot $\mathrm{N}$ content.

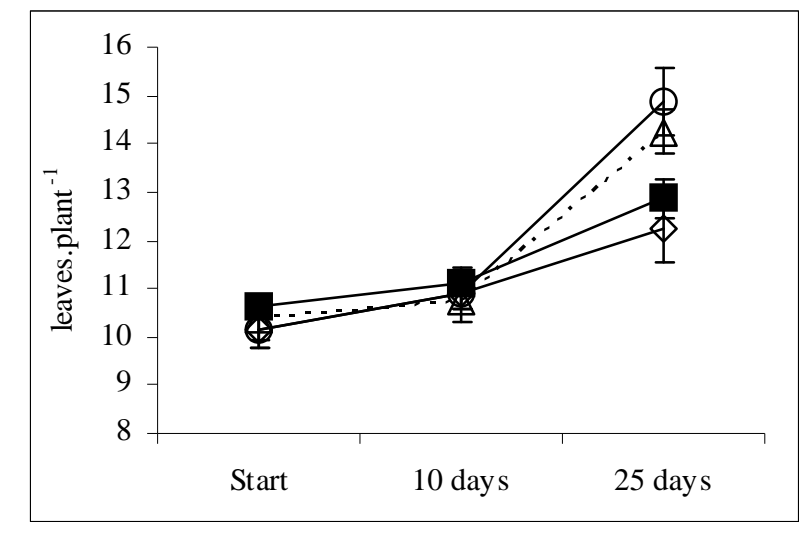

Figure 2 - Number of leaves in maté seedlings in response to $\mathrm{N}$ source and time after treatments ( $\diamond$ control; $\boldsymbol{\square}$ urea; $\triangle$ nitrate; $\bigcirc$ ammonium).

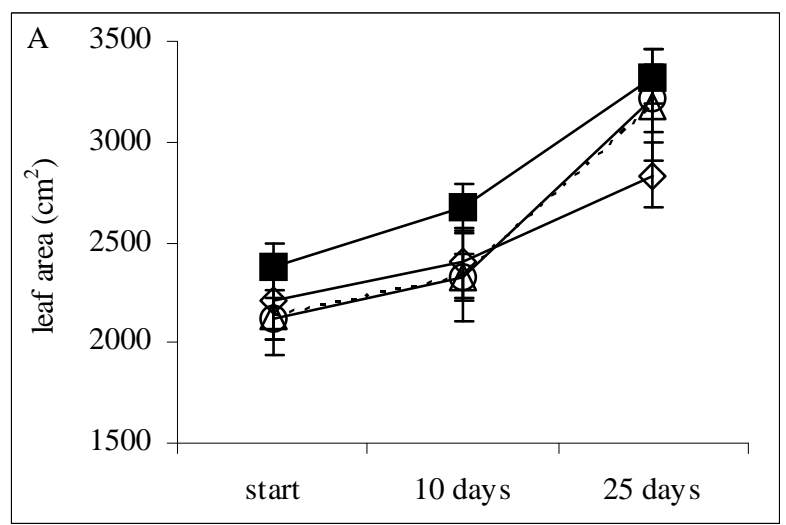

Figure 3 - Leaf area $\left(\mathrm{cm}^{2} \cdot\right.$ plant $\left.{ }^{-1}\right)$ as a response to $\mathrm{N}$ source $(\diamond$ control, $\mathbf{\square}$ urea, $\triangle$ nitrate, $\bigcirc$ ammonium) 

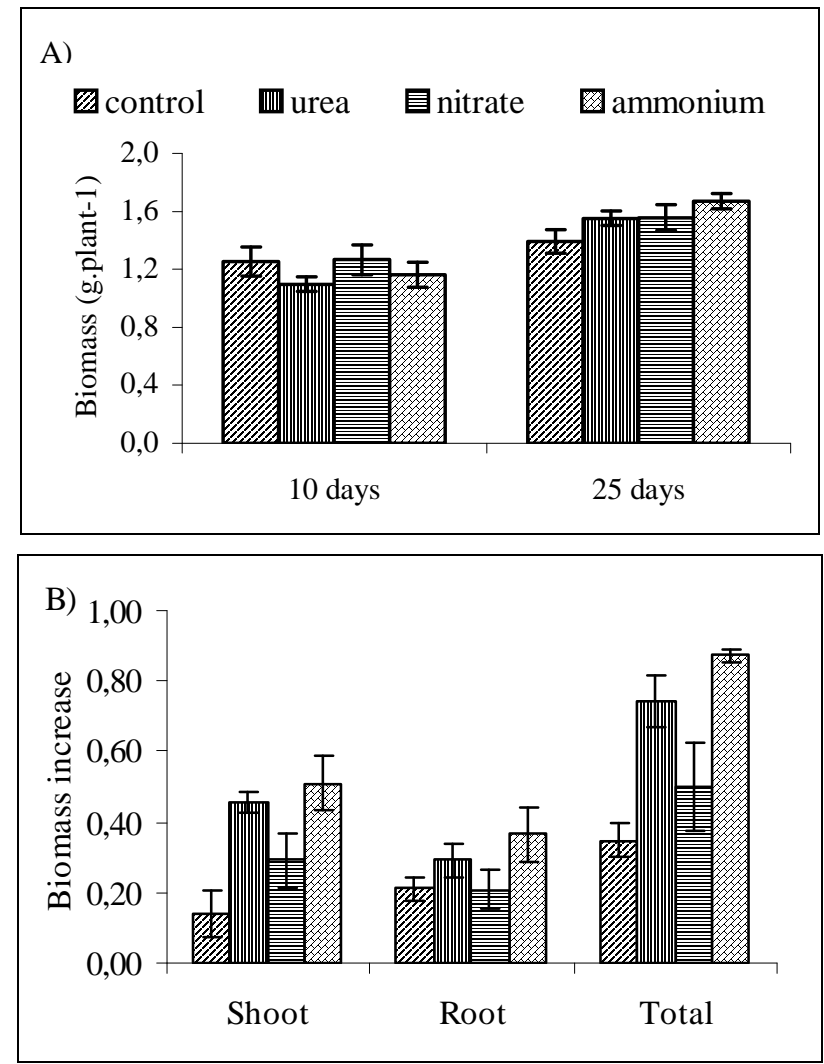

Figure 4 - (A) Shoot biomass (g. plant ${ }^{-1}$ ) of mate seedlings at the two harvests and (B) Biomass increase $\left(\mathrm{g}\right.$. plant $\left.{ }^{-1}\right)$ between the two harvests in shoot, root and total biomass according to $\mathrm{N}$ source.

Table 1 - Nutrient accumulation (mg.plot $\left.{ }^{-1}\right)$ in the shoot biomass of mate seedlings between the $10^{\text {th }}$ and the $25^{\text {th }}$ day after treatment application

\begin{tabular}{l|c|c|c|c}
\hline Nutrient & Control & Urea & Nitrate & Ammonium \\
\hline $\mathrm{N}^{\mathrm{a}}$ & $7.36 \mathrm{~b}$ & $56.39 \mathrm{a}$ & $58.61 \mathrm{a}$ & $71.51 \mathrm{a}$ \\
\hline $\mathrm{P}$ & $-1.08 \mathrm{~b}$ & $-0.09 \mathrm{ab}$ & $-0.66 \mathrm{~b}$ & $0.71 \mathrm{a}$ \\
\hline $\mathrm{K}$ & $-1.05 \mathrm{~b}$ & $17.06 \mathrm{a}$ & $11.95 \mathrm{ab}$ & $21.58 \mathrm{a}$ \\
\hline $\mathrm{Ca}$ & $2.83 \mathrm{~b}$ & $6.54 \mathrm{~b}$ & $21.78 \mathrm{a}$ & $7.01 \mathrm{~b}$ \\
\hline $\mathrm{Mg}$ & $2.95 \mathrm{~b}$ & $6.89 \mathrm{ab}$ & $3.64 \mathrm{~b}$ & $8.30 \mathrm{a}$ \\
\hline $\mathrm{Cu}$ & $-.0008 \mathrm{~b}$ & $0.0200 \mathrm{a}$ & $0.0037 \mathrm{ab}$ & $0.0100 \mathrm{ab}$ \\
\hline $\mathrm{Fe}$ & $0.1563 \mathrm{a}$ & $0.3320 \mathrm{a}$ & $0.1383 \mathrm{a}$ & $0.4079 \mathrm{a}$ \\
\hline $\mathrm{Mn}$ & $-0.0637 \mathrm{a}$ & $1.4060 \mathrm{a}$ & $0.1728 \mathrm{a}$ & $0.9682 \mathrm{a}$ \\
\hline $\mathrm{Zn}$ & $-0.0845 \mathrm{a}$ & $0.1336 \mathrm{a}$ & $0.0200 \mathrm{a}$ & $0.1204 \mathrm{a}$ \\
\hline
\end{tabular}

${ }^{\text {a }}$ - values followed by the same letter, in the line, do not differ at $10 \%$ of probability according to Tukey Test.

Pn was very similar among treatments at the first measurement however there were strong changes with time (Fig. 6). Seedlings from all $\mathrm{N}$ treatments had an increase in Pn after fertilization in both, old and new leaves which confirmed the results on the total $\mathrm{N}$ content. Maté seedlings fertilized with $\mathrm{N}$ -
$\mathrm{NH}_{4}$ source presented higher $\mathrm{Pn}$ in both, old and new leaves (Fig. 6). Pn was similar in new leaves and in old leaves at the $\mathrm{N}-\mathrm{NH}_{4}$ source on the $25^{\text {th }}$ day. 


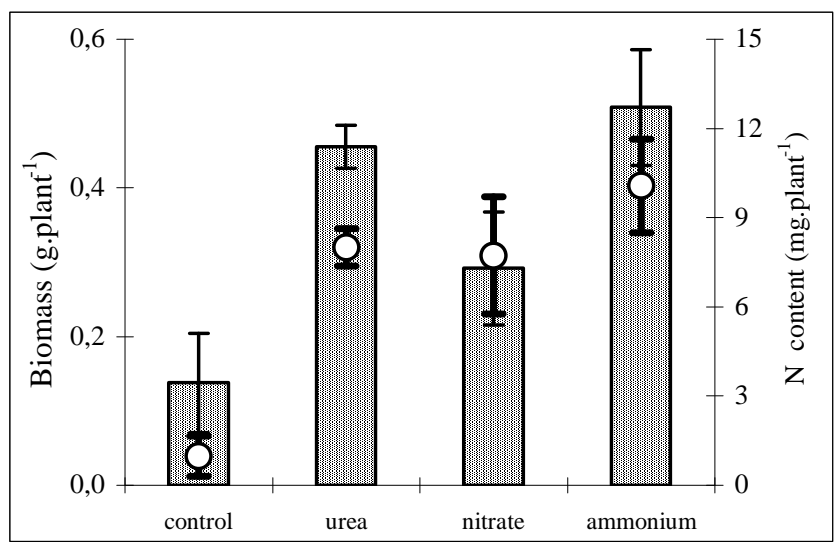

Figure 5 - Effect of N source on shoot biomass (column) and N content in shoot (circles)
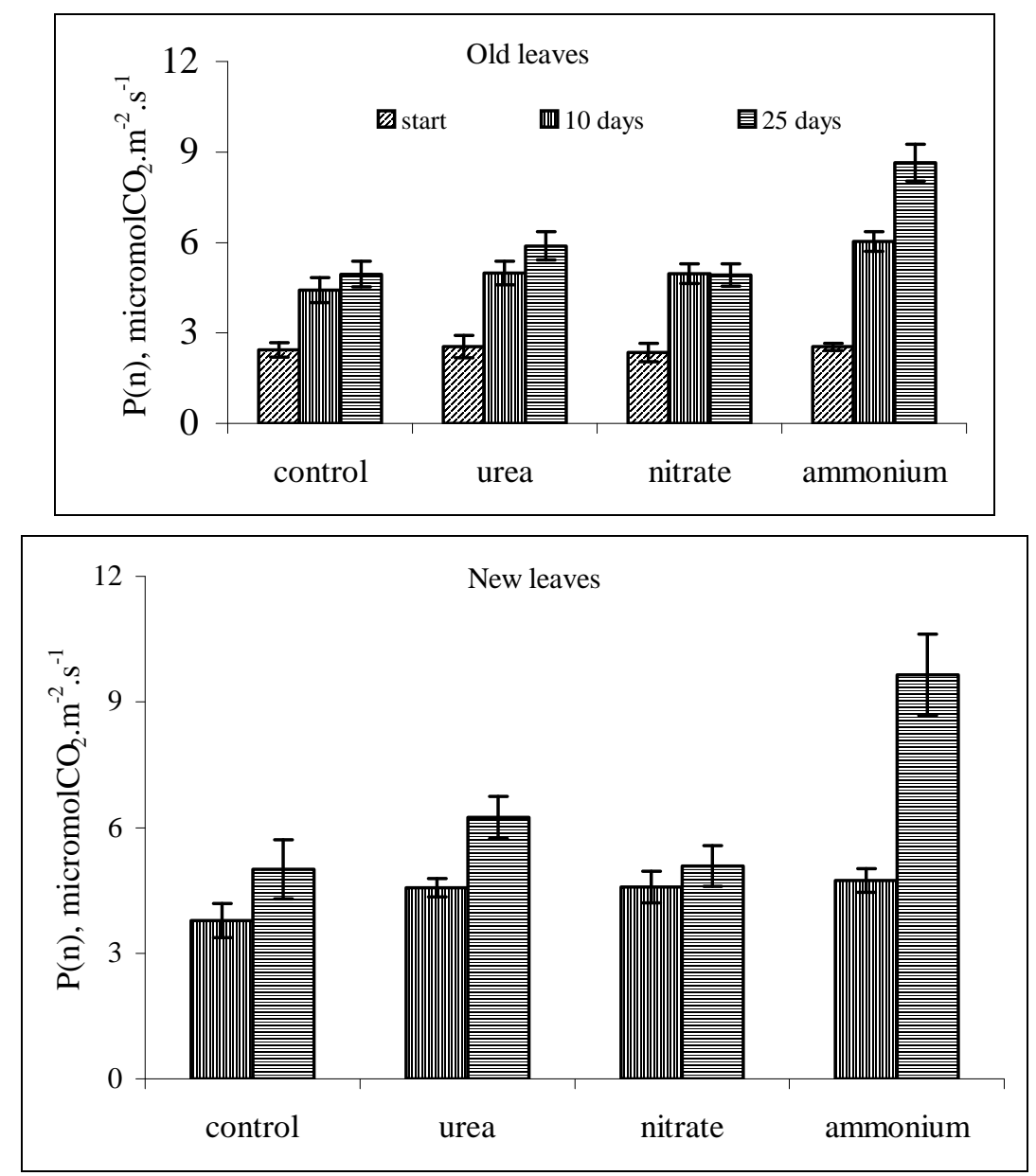

Figure 6 - Effect of $\mathrm{N}$ source on net photosynthesis (Pn) in old and new leaves of maté according to time after treatment application. 


\section{DISCUSSION}

The radiation level inside the greenhouse was satisfactory to maté seedlings development according to results of $\mathrm{Pn}$ and stomata conductance from field (Rakocevic, unpublished data) where the Photosynthetic Photon Flux Density(PPFD) levels higher than $800 \mu$ mol.m- ${ }^{2} . \mathrm{s}^{-1}$ were able to inhibit photosynthesis in leaves at the canopy border in pruned maté trees. Considering PPFD relatively low during the experiment the radiation would not interfere on the growth of maté seedlings. Measurements were made during the period of highest annual response to Pn of this species, which occurs from October to February (Galvão, 1986), permitting the distinction on assimilatory responses of young and mature leaves.

Low ratios R:FR may promote distinct photomorphogenetics reactions (Aphalo et al., 1999), depending on plant species (VarletGrancher et al., 1993). Maté tolerate shadow at any time of its cycle being able to accept higher light intensity at the adult stage (Carvalho, 1994), moreover the red : far red ratio (R:FR) was not modified in greenhouse.

The use of different $\mathrm{N}$ sources affected growth of maté seedlings in different ways. Plants fertilized with the $\mathrm{N}-\mathrm{NH}_{4}$ source presented higher number of leaves and increased branching. Plants fertilized exclusively with $\mathrm{N}-\mathrm{NH}_{4}$ show higher sensibility to high irradiation than plants submitted to low irradiation (Zornoza et al., 1987). Leaf area per plant (LA) receiving Urea as $\mathrm{N}$ source was higher than those receiving the sources $\mathrm{N}-\mathrm{NO}_{3}$ and $\mathrm{N}$ $\mathrm{NH}_{4}$, ten days after fertilization (Fig. 3). However, there was no difference among treatments 25 days after fertilization. Some studies showed a decrease in LA in plants nourished with $\mathrm{N}-\mathrm{NH}_{4}$ (Lips et al., 1990; Raab and Terry, 1994), although this did not mean necessarily a decease in Pn per unit of area (Takács and Técsi, 1992).

The highest total biomass was recorded at $\mathrm{N}-\mathrm{NH}_{4}$ and Urea treatments (Fig. 4B). The increase in number of new leaves from the application of $\mathrm{N}$ sources did not interfere on biomass increase for the $\mathrm{N}-\mathrm{NO}_{3}$ treatment, whereas urea plants which did not present an increase in number of leaves had a significant increase in biomass despite having a similar number of leaves to the Control treatment (Fig. 3A).

Plants that received any $\mathrm{N}$ source had a higher accumulation of $\mathrm{N}$ in shoot biomass than control, especially those grown on $\mathrm{N}^{-\mathrm{NH}_{4}}$ source. Considering the lowest increase of shoot biomass in $\mathrm{N}-\mathrm{NO}_{3}$ plants comparing to other $\mathrm{N}$ treatments (Fig. 4), no difference in $\mathrm{N}$ shoot content comparing to other $\mathrm{N}$ treatments (Fig. 5), and the lower Pn rates in the $\mathrm{N}-\mathrm{NO}_{3}$ comparing to $\mathrm{N}-\mathrm{NH}_{4}$ plants (Fig. 6), it was reasonable to hypothesize that the $\mathrm{N}-\mathrm{NO}_{3}$ plants invested more on structural shoot proteins production than in protein acting on photosynthesis. The photosynthetic capacity in species were highly correlated to $\mathrm{N}$ concentration on leaves due to the larger fraction of leaf $\mathrm{N}$ allocated at the photosynthetic apparatus (Hikosaka and Hirose, 2000). N deficit necessarily promote a remobilization of $\mathrm{N}$ from Rubisco (Paul and Foyer, 2001). Therefore, decreasing the leaf biomass, there was a decrease in leaf protein content which lead to a decrease in net photosynthesis due to nitrogen (Soussana et al., 2000). The net photosynthesis was favored by N$\mathrm{NH}_{4}$ application compared to $\mathrm{N}-\mathrm{NO}_{3}$ source and control (Fig. 6). The young leaves emitted after the $\mathrm{N}$-treatments reached high gas exchange rates even before their full expansion, and the mature leaves increased the net photosynthetic rate with time.

Claussen and Lenz (1999) highlighted that net photosynthesis may increase or decrease when plants are nourished with $\mathrm{N}-\mathrm{NH}_{4}$ source depending on plant species, and on the $\mathrm{pH}$ of the nutrient solution. Vaccinium corymbosum, from acidic soil, did not respond positively to liming, showing that plants from acidic soils with high levels of organic matter increased the net assimilation as much as the chlorophyll content on the application of $\mathrm{N}^{-\mathrm{NH}_{4}}$. Maté grew even in soils with $\mathrm{pH}$ $\left(\mathrm{CaCl}_{2}\right)$ up to 3.4 (Lourenço, 1997), and also did not respond positively to liming (Reissmann et al., 1989, 1991, 1997; Pintro et al., 1998). Therefore, when determining the fertilization form one should always analyze the origin of species.

Most plant species, which react positively to $\mathrm{N}$ $\mathrm{NH}_{4}$ as compared to $\mathrm{N}-\mathrm{NO}_{3}$, increase $\mathrm{Pn}$, diminish LA, and invest more on root biomass production, but do not affect the total biomass production (Wiesler, 1997). Maté strategy to $\mathrm{N}^{-\mathrm{NH}_{4}}$ comparing with $\mathrm{N}-\mathrm{NO}_{3}$ was an increase in $\mathrm{Pn}$ (Figs. 6A and 6B) with no effect on LA (Fig. 3), investing relatively more in shoot biomass production (Fig. 4B) and with no effect on final biomass production (Fig. 4A). The lower $\mathrm{N}$ photosynthetic efficacy of $\mathrm{N}-\mathrm{NO}_{3}$ plants were probably related to their $\mathrm{N}$ investment focalized 
more in structural shoot proteins production rather than in photosynthetic active proteins.

Growth and net photosynthesis of maté seedlings were higher in plants nourished with $\mathrm{N}_{-} \mathrm{NH}_{4}$ comparing to $\mathrm{N}-\mathrm{NO}_{3}$, and there was no difference to urea treatment, demonstrating relation to changes in $\mathrm{pH}$ of the rhizosphere soil and correlated parameters (Marshner, 1995). Maté seedlings showed a higher LA as well as net photosynthesis in plants that received the $\mathrm{N}_{-} \mathrm{NH}_{4}$ source differing from some other species from acidic soils that usually showed an increase in net photosynthesis per unit area but presented a diminishing LA when plants were nourished with $\mathrm{N}-\mathrm{NH}_{4}$. The increased absorption of $\mathrm{P}$ and $\mathrm{Mg}$ (Table 1) reflected directly on the net photosynthesis observed in this treatment. New experiments on field conditions should be crossed out considering different development stages of plants, soil types and climate conditions aiming to confirm the preference of $\mathrm{N}-\mathrm{NH}_{4}$ source over the others as shown in this experiment.

\section{ACKNOWLEDGMENTS}

M.R. was IICA international consultant and CNPq Invited Researcher. Thanks are due to Guilherme Erthal Risi and Ulysses Rocha Netto for technical assistance.

\section{RESUMO}

A influência de diferentes fontes de $\mathrm{N}$ sobre o crescimento de mudas de erva-mate (Ilex paraguariensis St.Hil.) foi estudada, em casa de vegetação. Todas as mudas receberam uma fertilização base de $10 \mathrm{mg} \mathrm{N} \cdot \mathrm{kg}^{-1}$ de solo na forma de $\mathrm{NH}_{4} \mathrm{NO}_{3}, 60 \mathrm{mg} \mathrm{P}_{2} \mathrm{O}_{5} \cdot \mathrm{kg}^{-1}$ e $40 \mathrm{mg} \mathrm{K}_{2} \mathrm{O}_{2} \mathrm{~kg}^{-1}$ de solo na forma de $\mathrm{KH}_{2} \mathrm{PO}_{4}$ quinze dias antes da aplicação dos tratamentos. Os tratamentos foram os seguintes: Controle, sem adição extra de N; Uréia $=100 \mathrm{mg} \mathrm{N} \cdot \mathrm{kg}^{-1}$ de solo como Uréia; $\mathrm{NO}_{3}{ }^{-}=$ $100 \mathrm{mg} \mathrm{N} \cdot \mathrm{kg}^{-1}$ de solo como $\mathrm{Ca}\left(\mathrm{NO}_{3}\right)_{2}$; $\mathrm{e} \mathrm{NH}_{4}{ }^{+}=$ $100 \mathrm{mg} \mathrm{N} \cdot \mathrm{kg}^{-1}$ de solo como $\left(\mathrm{NH}_{4}\right)_{2} \mathrm{SO}_{4}$. Concluiuse que: 1) o aumento do conteúdo de $\mathrm{N}$ nas folhas, por si, não é capaz de promover ganhos na produção de biomassa em mudas de erva-mate; 2) mudas que receberam $\mathrm{N}-\mathrm{NH}_{4}$ apresentaram maior acumulo de $\mathrm{P}$ e $\mathrm{Mg}$ na biomassa aérea; e 3) o aumento na absorção de $\mathrm{P}$ e $\mathrm{Mg}$ coincidiu com um aumento na área foliar, no número de folhas e na fotossíntese liquida na fonte $\mathrm{N}-\mathrm{NH}_{4}$.

\section{REFERENCES}

Aphalo, P. J.; Ballaré, L. C. and, Scopel, A. L. (1999), Plant-plant signaling, the shade avoidance response and competition. Journal of Experimental Botany, 50, 1629-1634.

Beltrano, J.; Ronco, M. G.; Barreiro, R. and Montaldi, E. R. (1999), Plant architecture of Paspalum vaginatum Schwartz modified by nitrate and ammonium nutrition, Pesquisa Agropecuária Brasileira, 34, 1159-1166.

Carvalho, P. E. R. (1994), Espécies florestais brasileiras: Recomendações silviculturais, potencialidades e uso da madeira. Brasília: EMBRAPA, SPI/CNPF.

Claussen, W. and Lenz, F. (1999), Effect of ammonium or nitrate nutrition on net photosynthesis, growth, and activity of the enzimes nitrate reductase and glutamine synthetase in blueberry, raspberry and strawberry. Plant and Soil, 208, 95-102.

Dedecek, R. A (1997), Manejo de solos em ervais. In: Congresso Sul-Americano da Erva-Mate; Reunião Técnica do Cone Sul sobre a Cultura da Erva-Mate, 2., Curitiba. Anais... Curitiba. pp. 317-336.

EMBRAPA (1979), Manual de métodos de análise de solo. Rio de Janeiro: EMBRAPA-SNCLS.

Farquhar, G. D.; Von Caemmerer, S. and Berry, J. A. (1980), A biochemical model of photosynthetic $\mathrm{CO}_{2}$ assimilation in leaves of $\mathrm{C} 3$ species. Planta, 149, 78-90.

Galvão, F. (1986), Variação sazonal da fotossíntese líquida e respiração de Cabrela canjeana (Vell.) Mart., Ilex paraguariensis St. Hil. e Podocarpus lambretii $\mathrm{Kl}$. em função da intensidade luminosa $e$ temperatura. $\mathrm{PhD}$ Thesis, UFPR, Curitiba, Brasil.

Hikosaka, K. and Hirose, T. (2000), Photosynthetic nitrogen-use efficiency in evergreen broad-leaved woody species coexisting in a warm-temperate forest. Tree Physiology, 20, 1249-1254.

Hoppe, M.; Knopp, E. and Medrado, M. J. (1996), Erva-mate: diagnóstico e perspectivas de desenvolvimento. Venâncio Aires. pp. 7-22.

Imsande, J. and Touraine, B. (1994), N demand and the regulation of Nitrate Uptake. Plant Physiology, 105, 3-7.

Kandlbinder, A.; Cruz, C. and Kaiser, W. M. (1997), Response of primary plant metabolism to the Nsource. Z. Pflanzenernähr. Bodenk., 160, 269-274.

Lips, S. H.; Leidi, E. O.; Silberbush, M.; Soores, M. I. M. and Lewis, E. M. (1990), Physiological aspects of ammonium and nitrate fertilization. Journal of Plant Nutrition, 13, 1271-1289. 
Lourenço, R. S. (1997), Adubação da erva mate. In: Congresso Sul-Americano da Erva-Mate; Reunião Técnica do Cone Sul sobre a Cultura da Erva-Mate, 2., Curitiba. Anais... Curitiba. pp. 299-315.

Marschner, H. (1995), Mineral nutrition of higher plants. $2^{\text {nd }}$ ed. London: Academic Press.

Marschner, H. and Romheld, V. (1996), Root-induced changes in the availability of micronutrients in the rhizosphere. In: Waisel, Y.; Eshel, A. and Kafkafi, U. (Eds.). Plant roots: the hidden half. $2^{\text {nd }}$ ed. New York: Marcel Dekker. pp. 557-579.

Oliveira, Y. M. M. and Rotta, E. (1985), Área de distribuição natural de erva-mate (Ilex paraguariensis St.Hil.). In: Seminário Sobre Atualidades E Perspectivas Florestais, Silvicultura da erva-mate (Ilex paraguariensis St. Hil), 10., 1983, Curitiba. Anais... Curitiba. pp. 17-36.

Pate, J. S. (1973), Uptake, assimilation and transport of nitrogen compounds by plants. Soil Biol. Biochem., 5, 109-119.

Paul, M. and Foyer, C. H. (2001), Sink regulation of photosynthesis. Journal of Experimental Botany, 52, 1383-1400.

Pintro, J. C.; Matumoto-Pintro, P. T. and SchwanEstrada, K. R. F. (1998), Crescimento e desenvolvimento de mudas de erva-mate (Ilex paraguariensis St. Hil.) cultivadas em solo sob diferentes níveis de fertilidade. Acta Scientiarum, 20, 285-289.

Raab, T. K. and Terry, N. (1994), Nitrogen source regulation of growth and photosynthesis in Beta vulgaris L. Plant Physiology, 105, 1159-1166.

Raij, B. van (1991), Fetilidade do solo e adubação. São Paulo: Agronômica Ceres. 343 pp.

Reissmann, C. B.; Koeler, C. W.; Rocha, H. O. and Hildebrand, E. E. (1985), Avaliação da exportação de macronutrientes pela exploração da erva-mate. In: Seminário Sobre Atualidades E Perspectivas Florestais, Silvicultura da erva-mate (Ilex paraguariensis St. Hil), 10., 1983, Curitiba. Anais... Curitiba. pp. 128-139.

Reissmann, C. B.; Prevedello, B. M. S.; Trevisan, E. and Born, R. H. (1989/1991), Suscetibilidade da ervamate a clorose induzida pela calagem. Revista do Setor de Ciências Agrárias, 11, 273-278.

Reissmann, C. B.; Prevedello, B. M. S.; Quadros,, R. M. B. and Radomski, M. I. (1997), Production an foliar $\mathrm{N}, \mathrm{P}, \mathrm{K}, \mathrm{Ca}$, and $\mathrm{Mg}$ levels in erva-mate (Ilex paraguariensis St. Hil.) related to increasing base saturation levels. Arq. Biol. Tecnol., 40 : (1), 241-249.
Soussana, J. F.; Teyssonneyre, F. and Thiery, J. M. (2000), Un modèle dynamique d'allocation base sur l'hypothèse d'une co-limitation de la croissance végétale par les absorptions de lumière et l'azote. In: Maillard, P. and Bonhomme, R. (Eds.). Fonctionnement des peuplements végétaux sous contraintes environnementales. Paris: I.N.R.A. pp. 87-112.

Takács, E. and Técsi, L. (1992), Effects of $\mathrm{NO}_{3}{ }^{-} / \mathrm{NH}_{4}{ }^{+}$ ratio on photosynthetic rates, nitrate reductase activity and chloroplast ultrastructure in three cultivars of red pepper (Capiscum annuиm L.). Journal of Plant Physiology, 140, 298-305.

Varlet-Grancher, C.; Moulia, B.; Sinoquet, H. and Russel, G. (1993), Spectral modification of light within plant canopies: how to quantify its effects on the architecture of the plant stand. In: VarletGrancher, C.; Bonhomme, R. and Sinoquet, H. (Eds.). Crop structure and light microclimate: characterization and application. Paris: I.N.R.A. pp. 427-451.

Wiesler, F. (1997), Agronomical and physiological aspects of ammonium and nitrate nutrition of plants. Z. Pflanzenernähr. Bodenk., 160, 227-238.

Wisniewski, C.; Jinzenji, F.; Claro, A. M. and Souza R. M. (1996), Exportação de biomassa e macronutrientes com a primeira poda de formação da erva-mate na região de Pinhais-PR. Revista do Setor de Ciências Agrárias, 15, 179-186.

Zornoza, P.; Carpena, O.; Najera, A. and Penalosa, J, (1987), Effect of light intensity on $\mathrm{NH}_{4}$ tolerance in tomato plants. Plant and Soil, 102, 93-97.

Received: December 17, 2004; Revised: July 01, 2005; Accepted: June 05, 2006. 